\title{
An Examination of India's Pharmaceutical Industry Through the Lens of Dependency Theory
}

\author{
Bashar AbuAlghanam \\ bmabualghanam@randolphcollege.edu \\ Randolph College (Lynchburg, Virginia, USA)
}




\section{Introduction}

Dependency theory portrays certain countries as core countries and others as periphery countries. It portrays the relationship between the core and the periphery as a parasitic, and controlling, one. This paper examines global pharmaceuticals through the lens of dependency theory, which would predict that core countries try to exert control over the pharmaceutical industry in periphery countries through patents, licensing, capital controls or other means. They also extend their activities to conducting pharmaceutical testing of dangerous drugs in Third World (or periphery) countries. Evidence suggest that there is a history of major multinational pharmaceutical companies, which are headquartered in developed countries, monopolizing lifesaving drugs and marketing unnecessary medical consumer products in periphery third world countries.

The case of India, however, took a different discourse that cannot be fully explained within the framework of dependency theory; the Indian pharmaceutical industry has witnessed an impressive growth over the past several decades. Several multinational pharmaceutical companies headquartered in industrialized and developed countries, and mainly the United States, commenced their operations in India. These companies maintained monopoly control over India's drug supply. Initially, this step created a quasi-dependency relationship. Quasi-dependency refers to a semi-dependency relationship that does not satisfy all the core tenants of dependency theory. The ways in which India's pharmaceutical industry developed ran contrary to the expected outcomes that dependency theory outlines; it exhibited its own mechanisms of control between India and the United States. In a sense, the Indian pharmaceutical industry witnessed a major shift from being a foreign-reliant industry to a self-reliant one. Eventually, the Indian pharmaceutical 
industry extended its influence in the form of competition to the U.S pharmaceutical market, and subsequently India's influence reflected in U.S markets as price competition between Indian and U.S generic manufactures. These changes in India's pharmaceutical industry are a result of several government legislations that were passed in support of manufactured generics in India- something that lead to India becoming a quality source of cheap, essential, drugs. This shift of power is significant because it shows that former dependent states can reverse the dependency relationship with the core.

This paper will examine the mechanisms by which the Indian pharmaceutical industry reversed the dependency relationship with the United States. A section follows that explores the various legislative amendments and structural changes that were undertaken by the Indian government to regulate and empower its pharmaceutical industry. To show the increased reliance of the core on the periphery in India's case, the paper will present case studies of two drugs that are being imported into the United States from India mainly because of the price disparities. This paper will argue that dependency theory cannot fully explain the reversed dependency relationship of India's pharmaceutical industry.

\section{Literature review}

In his paper Dependency Theory: An Introduction, Ferraro traces the roots of dependency theory to the $1950 \mathrm{~s}^{1}$. He attributes its development to Raúl Prebisch, director of the United Nations Economic Commission for Latin America at the time. Prebisch suggested that economic growth in industrialized countries does not result in genuine development in poorer countries. In fact, he argued that this relationship makes poorer countries worse economically in that it created more economic development problems. At the time, these outcomes were not predicted by neoclassical

\footnotetext{
${ }^{1}$ Ferraro, V. (1996). Dependency Theory: An Introduction.
} 
theory, which argued that economic growth is beneficial to all countries involved. Prebisch's proposed solution was for poor countries to participate in import substitution, whereby they would replace foreign imports with domestic production in order to cut the ties of dependency. ISI largely fails due to several reasons. The first is related to the economies of scale in poor countries, which cannot sustain low prices similar to rich countries. The second issue questions the political will and desire of poor countries to implement an import substitution program. Finally, the third issue is concerned with the extent to which poor countries have control over their primary resources.

As for the relationship between the core and periphery, Prebisch contends that poor countries export commodities to rich countries, whereby the commodities are used to manufacture goods that are resold to the poor countries. The value added from the manufacturing process usually exceeds what the poor countries earn from imports. Ferraro argues that most dependency theorists agree that the capitalism is the grand motive behind dependency relationships. For them, capitalism is the foundation of the existing division of labor system, which eventually leads to poverty and underdevelopment. Within this system, the functions of dependent states are to: supply cheap minerals, agricultural commodities, cheap labor, serve as the repositories of surplus, capital, obsolescent technologies, and manufactured goods. These functions orient the dependent states towards the outside. Another assumption of dependency theory, which it shares with Marxist theory, is that political and economic powers are heavily based in core countries. This means that core countries will take whatever measures necessary in pursuit of protecting their private economic interests.

Ferraro defines dependency theory as "an explanation of the economic development of a state in terms of the external influences--political, economic, and cultural--on national development 
policies." ${ }^{2} \mathrm{He}$ also lists the following features of the theory, which most dependency theorists share:

- The binary view of the world countries as core/periphery

- The existence of external forces, which are important to control the economic activities in dependent states (e.g "multinational corporations, international commodity markets, foreign assistance, communications")

- The nature of the relationship between the two core/periphery states is dynamic and reinforcing ${ }^{3}$.

Dependency theory has several central propositions. Ferraro summarizes these propositions as follows:

- Dependency theory emphasizes the distinction between undevelopment and underdevelopment

- Poor countries are poor because of coercion into the European economic system (not because they are lagging behind scientifically)

- Alternative economic practices are preferable to those practices imposed by dominant (core) states

- There exists a national economic interest for each country (especially periphery countries) better than the alternative (use of resources by the dominant country)

The elite in the dependent country play a role in giving the dominant countries power

Ferroro's analysis lays out the basic model of dependency theory, which is important in that it facilitates highlighting the failures of the theory in explaining the operational variables of India's pharmaceutical industry. These failures are found in the definition, core propositions and core tenants of dependency theory. India's pharmaceutical industry broadly challenges the main claims that dependency theory makes about the relationship between the core and the periphery.

To portray a prominent case that exhibits the characteristics of a dependency relationship, Geriffi uses the Mexican steroid hormone industry as an example. In his paper Drug firms and dependency in Mexico ${ }^{4}$, Geriffi states that the steroid hormone industry is dominated by foreign

\footnotetext{
${ }^{2}$ Ferraro, V. (1996). Dependency Theory: An Introduction.

3 ibid

${ }^{4}$ Gereffi, G. (1978). Drug firms and dependency in Mexico: The case of the steroid hormone industry. International Organization Int.

Org
} 
multinational corporations. He argues that the corporations' relationship with Mexico is a dependency relationship as reflected by two conditions. He presents evidence that the economic growth resulting from Mexico's steroid hormone industry unequally benefited the foreign multinational corporations (and their respective headquarters countries) more than Mexico. Second of all, when it came to domestic Mexican policy, there have been several restrictions on local development options because such options were in conflict with the interest of the multinational corporations and their head countries.

According to Geriffi, Mexico tried to weaken the influence of the multinational corporations by exercising more autonomy over their local national firm that produced raw materials for the manufacture of steroid hormones; however, this was not a successful effort. To begin with, the multinational corporations were finding several alternatives for Mexico as a source of raw materials. But more importantly, the corporations had influence on local political figures ${ }^{5}$. Once again, this situation reflects one of the central propositions of dependency theory; the elites of Mexico (the dependent state) are furthering the interest of the multinational corporations and their own interests as well (representing the core countries). Geriffi's analysis is central to this paper in that shows a clear case of a dependency relationship in a sub-sector of Mexico's pharmaceutical industry. When compared, the cases of Mexico and India show the selective applicability of dependency theory, whereby the theory can account for Mexico's context but not for India's.

Dr. Sunil Sahu, in his examination of the Indian pharmaceutical industry argues that the existence of a multinational corporation in a host country shifts the bargaining position or advantage from the corporation to that country ${ }^{6}$. He makes his argument by examining India's

${ }^{5}$ ibid

${ }^{6}$ Sahu, S. (n.d.). Globalization and the Indian Pharmaceutical Industry. 
pharmaceutical industry from the scope of bargaining power theory. This theory suggests that the relative power balance between multinational corporations and their host countries might shift over time, which will eventually lead to pressure for re-negotiation ${ }^{7}$. Sahu makes this argument by examining the initial monopoly power the multinational corporations were able to acquire in India. Then he goes on to examine how the Indian government reversed that monopoly power by implementing structural and legislative changes in the pharmaceutical industry. In general, Sahu describes the state of the Indian pharmaceutical industry as having "gone from a state of total dependence on transnational firms in the first two decades of independence to one of relative selfreliance in the 1980s and early 1990s". To backup his claims, Sahu utilizes a survey of the growth of the Indian pharmaceutical industry, which was conducted over years, divided into four phases. Sahu's paper explores the factors and the variables involved in the emergence of India's pharmaceutical industry. These factors and variables serve as a thorough explanation of the ways in which this paper argues that India transformed the dependency relationship with United States.

The United States pharmaceutical market is the largest in the world, which puts it in a critical position and makes it a target for exports by generic manufactures worldwide. In terms of the implications for the U.S drug market, Greene $(2007)^{8}$ argues that after the Indian government amended its patent laws, which legally allowed the copying and "reverse engineering" of foreign drugs, the local pharmaceutical companies compensated for this shift in revenue by turning to exports - mainly to the United States- and foreign acquisition. Evidence in Greene's paper suggests that the United States pharmaceutical market is facing a problem with the supply of generic drugs. The generic drug producing firms are pulling out of the market because of a major decrease in

\footnotetext{
${ }^{7}$ Levy, D. L., \& Prakash, A. (2003). Bargains Old and New: Multinational Corporations in Global Governance. Business and Politics, 5(2). doi:10.2202/1469-3569.1051

8 Greene, W. (2007). The Emergence of India's Pharmaceutical Industry and Implications for the U.S. Generic Drug Market.
} 
revenue and profits. To explain the decreases in revenues and profits, the paper lists the following reasons: "price erosion, the introduction of authorized generics by innovator companies, and the entry of additional suppliers from low-cost countries into the market". Furthermore, Greene explores the influence of Indian generic manufacturers on the U.S drug market. He argues that Indian generic manufactures posed the challenge of fierce competition for U.S generic manufactures, which explains a major part of the decrease in U.S manufacturers"' revenue. In the context of this paper, Greene's analysis provides evidence for how the core is able to influence the periphery's economy. In the context of contemporary conditions, this challenges dependency theory, which would predict the opposite.

In his paper The Rise and Fall of the Dependency Movement, Omar Sánchez looks at the emergence of dependency theory in the context of Latin America, and he attributes its academic prevalence to being a "Latin American analysis of Latin American development"'. Moreover, Sánchez argues that dependency theory held a significant position as being one of the rare instances, whereby an idea produced in the Third World influenced the work of thinkers and scholars in the developed world. Sanchez rejects the idea of dependency as being a theory and rather calls it an overarching approach. His rationale is that dependency, unlike a theory, does not "predict determinate, discrete outcomes"10, but it rather provides a perspective from which economic problems can be examined. The paper further argues that the most significant intellectual flaw of dependency theory is the lack of an empirical component to prove its outcomes; the basic elements of dependency analysis (such as structural or global interpretation) lack empirical grounding; it is neither testable nor falsifiable, which makes it unscientific To this end, Sanchez attributes the basic flaws of dependency theory to several factors: the first factor is its claim that

\footnotetext{
${ }^{9}$ Sanchez, O. (2003). The Rise and Fall of the Dependency Movement: Does It Inform Underdevelopment Today? E.I.A.L. Logo Estudios Interdisciplinarios De América Latina Y El Caribe, 14(2). Retrieved April 18, 2016.

${ }^{10}$ ibid
} 
development is not possible within the framework of capitalism. This claim has been contradicted by the economies of South Korea, Singapore, Taiwan and Hong Kong in the late part of the twentieth century. Sanchez explains that these societies "can be considered to have joined the ranks of the developed world in their own right" The second factor is the evolution of economics as a profession, which increased reliance on theories that emphasized mathematical analysis. As mathematics became the sine qua non of economics, reception of dependency theory among economists changed; they categorized dependency theory under the political economy rather than economics. The third factor is the fall of socialist and communist regimes, which resulted in Marxism losing its appeal. Since dependency theory had major Marxism intellectual foundations, it was regarded as fundamentally flawed by virtue of association with Marxism ${ }^{11}$. Within the context of this paper, the emergence of India's pharmaceutical industry affirms the possibility of development within a global capitalist framework, which fundamentally disagrees with dependency theory. Despite the capitalist motives of the United States' MNCs, India's pharmaceutical industry managed to develop to the point of self-reliance within a capitalist framework.

Despite Latin America's position as the birthplace of dependency theory, arguments have been made to refute the theory's relevance in the Latin American context. In the paper $A$ Preliminary Test of the Theory of Dependency, Kaufman, Cherntosky and Geller present an empirical analysis of dependency theory's core propositions in an effort to refute the theory's claims in the Latin American case ${ }^{12}$. The authors provide a view of dependency in Latin America at two different levels; at one level, dependency is viewed as a perversion of the development

\footnotetext{
11 ibid

12 Kaufman, R. R., Chernotsky, H. I., \& Geller, D. S. (1975). A Preliminary Test of the Theory of Dependency. Comparative Politics, 7(3), 303. doi:10.2307/421222
} 
process in Latin America since Latin American countries have no control over the forces shaping their destiny. On another level, dependency theory is viewed as an alternative diagnostic framework or approach to the developmental issues in Latin America ${ }^{13}$. While other conventional theories view Latin America's development process as analogous with earlier development experiences in Europe and the United States, dependency theory ties Latin America's development to transnational structures and the international environment.

The paper offers several empirically testable categories of allegations made by dependency theorists: social stratification, economic performance, political infrastructure, and political system characteristics. These operational measures of the theory were tested against all Latin American countries; nonetheless, the following countries were excluded: Cuba (by virtue of its break with capitalist world), Haiti (by virtue of lack of available data) and Venezuela (by virtue of having bargaining power in the form of oil reserves) ${ }^{14}$. The empirical results of the study suggest that dependency theory requires refinement and redefinition as well; the theory should draw a distinction between capital and trade dependency. Moreover, the theory should highlight the specific commodity that is being exchange between the core and the periphery. Another imperative distinction that should be drawn is in regards to the type of dependency (cultural, political or military). The results further suggest that attention should be paid to political, social and cultural variables that can affect the consequences of economic dependency. Lastly, the study suggests that dependency theory's claims be toned down (especially the theory's claim to be a complete understanding of all of Latin America's problems). The findings of the study highlight the substantive nature of dependency theory's claims, which are to be refuted within the context of India's pharmaceutical industry. As affirmed by Kaufman, Cherntosky and Geller, India's distinct

\footnotetext{
13 ibid

14 ibid
} 
political variables affected the outcomes of economic dependency. These variables, as will later be discussed, were manifested in the form of legislation and politician support.

\section{The Armodafinil Case}

Armodafinil (brand-name Nuvigil) is a pharmaceutical drug used to treat narcolepsy, a condition characterized by sudden episodes of sleep onset, which could endanger a person if he is performing actions such as driving ${ }^{15}$. This drug comes as a development of its precedent drug Modafinil (brand-name Provigil). Armodafinil was approved by the FDA in $2007^{16}$; however, it recently became a more popular drug amongst late-shift workers, students and professionals. The reason is that it has potent wakefulness promoting properties, which makes it appealing to those who want an extra boost of energy. A study found that one in every five students has taken the $\operatorname{drug}^{17}$. Cephalon, a subsidiary of the American-Israeli pharmaceutical giant Teva, owns the manufacturing rights in the U.S ${ }^{18}$. The benefits of the drug, the low side effect profile, the low dependence liability, and the wide array of therapeutic areas it covers come at a price; as of April, 2016, the most current price for a single tablet of Armodafinil in the U.S is $\$ 28.04^{19}$. Amidst the high retail price of Armodafinil, and due to the distinct medical benefits it provides, those who need it started turning to a different source for acquiring the drug: India. There is a convincing reason as to why the users turned to India. In Indian pharmacies, ten tablets of Armodafinil of the same potency, strength, and manufacturing quality as the U.S, cost $\$ 2.252^{20}$-- that is $\$ 0.2252^{21}$ for a single tablet. By this logic, a tablet of Armodafinil from India is $\$ 27.81$ cheaper than the same

\footnotetext{
${ }^{15} \mathrm{http}: / / \mathrm{www}$. drugs.com/nuvigil.html

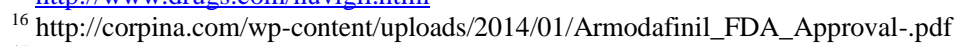

${ }^{17} \mathrm{http} / / /$ www.theguardian.com/education/abby-and-libby-blog/2014/may/08/one-in-five-students-have-taken-study-drug-modafinil

${ }^{18} \mathrm{http}: / /$ nuvigil.com/

${ }^{19}$ https://www.rxpricequotes.com/

${ }^{20} \mathrm{http}: / /$ www.medindia.net/drug-price/

${ }^{21} \mathrm{ibid}$
} 
tablet form the United States. As a result of increased importation of Armodafinil, which could further increase the competition in the U.S generic drug market, the FDA issued multiple importation bans on Armodafinil ${ }^{22}$; nonetheless, the imports continued coming into the United States through mail orders. In an effort to discourage Indian manufacterer's of Armodafinil from exporting the drug to the U.S, the FDA banned all imports from the primary India-based manufacturer of Armodafinil, which is Sun Pharma ${ }^{23}$.

This case study is important since it shows the transformation of dependency roles between India and the United States. Individuals in the United States are relying on Indian companies as a source of their medications. Through its central propositions, traditional dependency theory suggests that the United States would exploit India's resources (e.g. bulk raw formulations) to manufacture drugs, which it then re-sells in both U.S and Indian markets ${ }^{24}$. Furthermore, dependency theory argues that the U.S would impose control over India's pharmaceutical industry though multinational corporations. The Armodafinil case contradicts the theory's central propositions by showing a reversed form of dependency. It specifically disagrees with Prebisch's conception of dependency theory, which suggests that India should be importing medications from the U.S., thus highliting a glaring failure of dependency theory within the Indian context.

\section{The Daraprim Case}

Pyrimethamine (brand-name Daraprim) is an antimalarial pharmaceutical drug that is used to treat malaria, toxoplasmosis, and as an adjunct therapy for $\mathrm{HIV}^{25}$. The medical community unanimously agrees on the consensus that Daraprim is an essential drug used to treat lifethreatening conditions ${ }^{26}$. Unlike Armodafinil, Daraprim is not a new drug having been approved

\footnotetext{
${ }^{22} \mathrm{http}: / / w w w . r e u t e r s . c o m / a r t i c l e / u s-s u n-p h a r m a-i n d i a-f d a-i d U S B R E A 2 C 09 S 20140313$

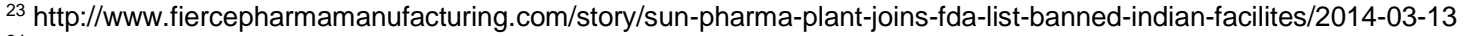

24 ibid

${ }^{25} \mathrm{http}: / /$ www.webmd.com/drugs/2/drug-634/daraprim-oral/details

${ }^{26} \mathrm{http}: / /$ www.usatoday.com/story/news/health/2015/09/18/company-hikes-price-5000-drug-fights-complication-aids-cancerdaraprim/32563749/
} 
by the FDA in 1953. This drug received significant media coverage in August 2015. During that month, the patent rights of the drug were acquired by a boutique pharmaceutical company called Turing pharmaceuticals, led by CEO Martin Shkreli. Prior to its acquisition, Daraprim only cost $\$ 13.5$ for a single tablet ${ }^{27}$, Turing pharmaceuticals raised the price of a single tablet from $\$ 13.5$ to $\$ 750-$ a $5,000 \%$ price hike ${ }^{28}$. This sudden price hike left patients using the drug with narrow options for sources of the drug, especially that many insurance companies stopped covering its prescriptions amidst the price increase.

Similar to Armodafinil, the price of Daraprim abroad, especially in India, is significantly cheaper ${ }^{29}$. For instance, the price of one tablet of Daraprim of the same potency and strength in India is around $\$ 0.10$ compared to $\$ 750$ in the United States $^{30}$. Subsequent to the price hike, several Indian online pharmacies started offering the drug at no more than $\$ 10$ per prescription ${ }^{31}$. Despite not having significant demand, Daraprim is an immensely critical drug for patients suffering from serious conditions such as $\mathrm{HIV}^{32}$. Dependency posits that India should be dependent on the United States for medications. Because of the recent nature of the price hike, there have been no recorded incidences of importation of Daraprim; however the cheap prices of Indian Daraprim generics combined with the price hike in the U.S is paving the way for an imminent reversal of dependency. Similar to Armodafinil, the U.S patients will most likely turn to sources such has India, thereby highlighting the core's dependence on the periphery for medication.

\footnotetext{
27 ibid

${ }^{28} \mathrm{http} / / /$ www.forbes.com/sites/johnlamattina/2015/09/21/heres-a-way-for-pharma-to-prevent-outrageous-generic-price-increasesand-help-its-reputation/\#ca5a75b31872

${ }^{29} \mathrm{ibid}$

${ }^{30}$ Daraprim: Generic version of drug costs less than $£ 0.07$ in India. (2015). Retrieved April 2, 2016, from

http://www.ibtimes.co.uk/daraprim-like-drug-costs-less-0-07-india-1521144

${ }^{31} \mathrm{ibid}$

32 (n.d.). Retrieved April 19, 2016, from http://www.latimes.com/business/hiltzik/la-fi-mh-that-pill-that-went-from-13-50-to-750-

20151023-column.html
} 


\section{Methedology}

This section outlines the operational variables that will later be used to compare India's pharmaceutical industry to a hypothetical dependency model. The following variables are derived from the core propositions of dependency theory. Each of the variables will assess an assumption that dependency theory proposes within the context of India's pharmaceutical industry. To assess these alleged assumptions, the variables have been categorized in four rubrics as follows:

- Mechanisms of control: This variable will examine which country is exerting control (or influence) over the other and by what means. In dependency theory, the core controls the periphery by means of the external forces such as: multinational corporations, international commodity markets, foreign assistance, and communications. Control can be observed when any of the mechanisms are used to influence the periphery in a manner that benefits the core. The mechanisms can be said to exert control when the actions taken through them are by the core. Moreover, the actions taken through these mechanisms should clearly result in disproportional benefits in favor of the core. Dependency theory argues that actions taken through these mechanisms are at odds with the interest of the periphery.

- The export-import relationship: This variable will examine the imports and exports between the two countries in an attempt to detect a dependency pattern. Dependency theory argues that while the periphery exports primary commodities to the core, it relies on imports of manufactured from the core country. The variable will measure the balance of imports and exports between the periphery and the core; it will assess whether the core or the periphery is the net exporter in the relationship. Furthermore, it will assess the nature 
of exports and imports being exchanged between the two countries (primary commodities vs. manufactured products).

- Elite influence: This variable will examine the role of the periphery country's elite in the dependency relationship between the two countries. One of dependency theory's main propositions argues that the periphery's elite make decisions that further the interest of the core. To measure this variable, the following will be assessed: the political and economic decisions taken by the periphery's elite and their net effect on both the core and the periphery, the influence of the core on the periphery's elite (whether through interference in the electoral process, donations to favorable parties or candidates, or offering financial incentives), and the positions of the periphery's elite on various legislations that favor the periphery.

- Functions of the periphery: This variable will examine the functions of the periphery country within the proposed dependency relationship. As suggested by dependency theory, periphery states serve to "supply cheap minerals, agricultural commodities, and cheap labor, and also serve as the repositories of surplus capital, obsolescent technologies, and manufactured goods" 33

For comparison purposes, a hypothetical dependency relationship model will be used to pinpoint the contrast points between India' pharmaceutical industry and dependency theory. The model will assume the existence of two virtual countries: Anasia (a core country) and Badea (a periphery country). We will further assume that Anasia is interacts with Badea, whereby Anasia imports primary commodities from Badea to manufacture antibiotics, which it then exports to Badea.

\footnotetext{
${ }^{33}$ Ferraro, V. (1996). Dependency Theory: An Introduction.
} 
In the hypothetical model, dependency theory suggests that Anasia will be exerting control over Badea through one or more of the aforementioned external forces. The control mechanism shall be through multinational corporations that operate in Badea. Through these MNCs, Anasia will be able to purchase the bulk materials at low prices. Alternatively, Anasia could use foreign aid that it provides to Badea as means of imposing control. The aid can be withheld in case Badea's government refuses giving access to Anasia's MNCs to raw material. In addition, the model assumes that the role of Badea's elites will be to further the interest of the Anasia and its MNCs. As for Badea's function, dependency theory suggests that it will serve as a source of raw materials, cheap labor, a repository of surplus capital, obsolescent technology and manufactured goods. This model, in contrast to India's pharmaceutical industry, will contribute to the clarity of the intellectual flaws of dependency theory in explaining the industry's emergence.

\section{Analysis}

In a hypothetical word, as set forth by Prebisch's explanation of dependency theory ${ }^{34}$, a core-country, like the United States would establish a relationship with India. In this relationship, the United States would utilize cheap resources (labor, raw/bulk materials, etc.) to manufacture pharmaceutical products. Using multinational corporations, the United States would proceed to export the manufactured goods back to India at a higher price. As suggested by theory, India's export revenues will be not offset its expenditure on the imported goods from the U.S. These products' costs would have embedded in them negative externalities that show up as symptoms in India. Moreover, any resultant economic, or otherwise, growth that this relationship produces would disproportionately benefit the United States and its multinational corporations in India.

${ }^{34}$ ibid 
According to Suhu, the first two phases (1948-1978) of the emergence of India's pharmaceutical industry were characterized by the entry of multinational and transnational foreign firms into India. At that time, India lacked a basic drug market, so the government's regulatory policy of the foreign firms was lenient; there were no laws regulating monopolies, pricing and patents, which allowed the MNCs to operate with more freedom ${ }^{35}$. To manufacture basic drugs, these firms established a monopoly over India's drug supply whereby they imported drug formulations from abroad and processed them into consumer products (capsules, tablets, etc.) in India. The end products by the MNCs flooded the Indian market at high prices. In addition, no domestic Indian companies were involved in the pharmaceutical industry. This model proved to be worrisome; these firms were refusing to manufacture essential, basic, drugs such as antibiotics (specifically penicillins), antidiabetics and other important drugs, which caused a shortage of these drugs in the Indian market. This situation shows the mechanisms of control at play in the form of foreign MNCs, which were used to exert influence over India' pharmaceutical market. Consequently, dependency theory's central propositions would suggest that this dependency relationship would continue by virtue of being dynamic and reinforcing.

Contrary to this proposition, the Indian government sought to break up the monopoly power of the multinational pharmaceutical companies, so it introduced the Monopoly and Restrictive Trade Practices Act, which examined the, and by virtue of size restricted, assets of large multinational drug companies..The government simultaneously passed the Foreign Exchange Regulation Act as well, which restricted local foreign ownership to 40 percent. These government actions led to a 100 percent increase in basic formulation production and a 400 percent increase in bulk drug production (consumer end-products). Furthermore, the Foreign Exchange Regulation Act resulted in a significant decrease in the market share of foreign companies. Prior to its passage in 1973, more than half of the multinational pharmaceutical companies in India had 100 percent foreign ownership of their subsidiaries. In 1974, India had 66 MNCs with foreign ownership; nonetheless, in the late 1980s, as a consequence of FERA, there were only six

${ }^{35}$ ibid 
companies left with foreign ownership in India's pharmaceutical market. The resultant radical decrease of foreign ownership in India's market subsequently meant less foreign influence as well. Another prominent legislation was The Indian Patent Act, which approved patents for processes not drugs. Instead of allowing a company to own rights to a drug, the act limited patents to only include the rights to a manufacturing process of a drug. The rationale behind this law was to allow Indian companies to manufacture drugs at cheap prices using a different process than the patented one. In 1959, the Ayyangar Committee produced a report, which examined the reasons behind India's high drug prices. The report concluded that monopoly control of foreign pharmaceutical companies in India as the leading cause of high drug prices. This report gave rise to the Indian Patent Act of 1970 s $^{36}{ }^{37}$. The collective results of government legislation disproportionately benefited India, where dependency theory would suggest the opposite. From that, the Indian government socialized the resultant benefits among the domestic pharmaceutical companies and the Indian consumers. Consequently, India's national sector's contribution to the pharmaceutical industry reached 65 percent in drug formulations and 83 percent in bulk drugs. The Indian patients were positively impacted by the lower cost of drugs; for instance, in March of 2012, through The Indian Patent Act, the controller general of patents office ordered Bayer to license Nexavar, a anti-cancer drug, to the Indian company Natco pharma. By doing so, Natco Pharma was able to produce the drug, while offering it at a cost of $\$ 176$ per month compared to Bayer's price of $\$ 5,600{ }^{38}$. In exchange for the license, Natco agreed to pay a 6 percent royalty fee to Bayer. This noteworthy decision facilitated the access of Indian consumers to a life-saving drug at a low cost. The disproportional benefits were reflected as a dis-advantage on Bayer's part; the company argued that the price of the drug should reflect developmental costs rather than the public's purchasing power. Another notable case of consumer advantage is the anti-cancer drug Herceptin. Given the life-saving nature of the drug, the Indian government forced Roche to surrender its patent of the

\footnotetext{
36 Product Patent for the Indian Pharmaceutical Sector under the TRIPS regime. (n.d.). Retrieved April 22, 2016, from http://www.legalserviceindia.com/articles/ppch.htm

${ }^{37}$ Sahu, S. (n.d.). Globalization and the Indian Pharmaceutical Industry.

${ }^{38}$ Bajaj, V., \& Pollack, A. (2012). India Orders Bayer to License a Patented Drug. Retrieved April 19, 2016, from http://www.nytimes.com/2012/03/13/business/global/india-overrules-bayer-allowing-generic-drug.html?_r=0
} 
drug $^{39}$. Recently, the Indian Biocon pharmaceuticals was awarded the generic manufacturing approval of the drug, which it promised to produce at a more affordable cost. Prior to striking the patent, an estimated 25,000 Indian woman would have benefited from the drug; however, only 1,500 were able to afford $\mathrm{it}^{40}$. The Indian government's decision comes in hopes that by allowing a local company to manufacture a generic, more people will be able to afford the drug.

The export-import relationship variable in the hypothetical model exhibits results in accordance with dependency theory. In India's case, the balance is reversed. According to Greene, India is the major, thirdworld country, exporter of generics to the United States. This is evidenced by the fact that India is home to the largest number of FDA-approved manufacturing plants outside the United States. Indian generic firms competing with major U.S pharmaceutical companies (such as Teva) lead to a decrease in the revenues of U.S generic manufacturers. In fact, at the going rate of Indian generic manufacturer growth in U.S markets, Greene expects that the Indian firms will start acquiring U.S companies. Some of the advantages that India has in terms of costs when compared to the U.S are significant; for instance, the cost of manufacturing a drug in India is less than half of the cost in the U.S. Moreover, clinical trials in India comprise almost onetenth the price of conducting the trials in the U.S. Lastly, the cost of research and development, which is critical to the pharmaceutical industry, is basically less than one eighth of the same cost in the United States $^{41}$. Based on the previous comparison, India is a major exporter of generics to the United States. Dependency theory would place India in a position as an exporter of primary commodities and as an importer of manufactured goods; however, this is not the case. India challenges its dependency role by exporting manufactured products to the United States. Secondary to legislative reforms, it can be argued that India implemented an import substitution industrialization policy. Evidence suggests that India replaced its foreign imports of medications with domestic production by virtue of self-reliance. The dynamics of India's ISI are noteworthy since the country went beyond self-reliance to become an exporter.

\footnotetext{
${ }^{39}$ Harris, G. (2013). India's Efforts to Aid Poor Worry Drug Makers. Retrieved April 19, 2016, from http://www.nytimes.com/2013/12/30/health/indias-efforts-to-aid-poor-worry-drugmakers.html?_r=0

40 ibid

${ }^{41}$ Greene, W. (2007). The Emergence of India's Pharmaceutical Industry and Implications for the U.S. Generic Drug Market.
} 
Within the context of the contemporary global economy, drug price laws can help in explaining the significance of India's ISI. The United States is the only country where medication prices are not subject to regulation, which plays a role in its higher drug costs. Conversely, India's lack of an adequate patent protection system contributes to its low drug prices. The combination of circumstances in both countries created a window of opportunity, which allowed India to become an exporter of drugs to the United States.

The role of the elite in the periphery is a major component of dependency theory. Ferraro contends that their role furthers the interest of the core. India's elite, which in this case are deemed to be the representatives of government, legislators, and decision makers, should be expected to further strengthen the influence of MNCs in India; nonetheless, India's elite role remained within the constraints of India's interests. A remarkable example of an elite pushing against multinational monopolies is Prime Minister Indira Gandhi; in 1970s, Ghandi advocated for the Indian Patents Act in an effort to provide the country's poor with access to low-cost drugs ${ }^{42}$. The rationale behind Gandhi's advocacy is that Indian companies would spend significantly less on research and development, which would result in lower medication prices. She was an outspoken advocate for access to cheaper medications and critical of patents. In 1981 at the World Health Assembly in Geneva, Gandhi addressed the audience saying: "Drug manufactures have become a powerful industry. My idea of a better- ordered world is one in which medical discoveries would be free of patents and there would be no profiteering from life or death. ${ }^{943}$ Moreover, the Indian government formed a national company called the Chemical and Pharmaceutical Corporation. This governmental entity provided high quality bulk and raw materials exclusively to local Indian drug companies at very low prices. Evidently, the roles of the elites led India to become capable of sell-reliance in that it started producing all essential drugs domestically ${ }^{44}$. The previously discussed roles of the elites cannot be construed as actions that further the core's interests. They are, however, an effort to further the interest of India, which dependency theory would suggest to be the periphery.

\footnotetext{
${ }^{42}$ Andrade, C., Shah, N., \& Chandra, S. (2007). The new patent regime: Implications for patients in India. Indian Journal of Psychiatry Indian J Psychiatry, 49(1), 56. doi:10.4103/0019-5545.31520

43 Product Patent for the Indian Pharmaceutical Sector. (n.d.). Retrieved April 22, 2016, from http://www.lawgratis.com/2016/02/04/product-

patent-for-the-indian-pharmaceutical-sector-under-the-trips-regime/

${ }^{44}$ Sahu, S. (n.d.). Globalization and the Indian Pharmaceutical Industry
} 
Lastly, the model explores the functions of the periphery as used by the core country.. When applying the 'periphery functions' variable to India, it shows functions that India served, which are at odds with dependency theory's core propositions. Instead of acting as a source of raw materials to the core, it was previously mentioned that the Indian government established a national bulk formulation company. By doing so, India's raw materials are still being used to manufacture drugs domestically, a significant part of which gets exported to core countries. In Ferraro's paper, one of the typical functions a periphery country would serve is as a repository of obsolescent technologies ${ }^{45}$; nonetheless, India contradicts that expectation. India's case further rejects dependency theory's assumption of the periphery being a suppository of obsolescent technology. As argued by Greene ${ }^{46}$, instead of solely focusing on the manufacturer of generics, Indian pharmaceutical companies are moving towards innovation, whereby they are improving on their research \& development infrastructure and focusing on technological licensings. This situates India as an aspiring innovator in the field of medical technology, which disrupts the dependency relationship further.

By examining the previously mentioned comparisons of the variables, it becomes evident that India's pharmaceutical industry is at odds with the outcomes outlined by traditional dependency theory. The results of the comparison suggest that economic development is possible within the capitalist framework of the world, which according to Sanchez took place in South Korea, Singapore, Taiwan and Hong Kong in the late $20^{\text {th }}$ century. The counter-arguments to dependency theory in the case of India's pharmaceuticals, within Sanchez's analysis, are that India's economic development was attainable, and that is was feasible through integration in the world economy ${ }^{47}$ (the former through the implementation of legislative and structural reforms and the latter through India's position as a generic drug export leader).

\footnotetext{
${ }^{45}$ Ferraro, V. (1996). Dependency Theory: An Introduction

46 ibid

${ }^{47}$ Sanchez, O. (2003). The Rise and Fall of the Dependency Movement: Does It Inform Underdevelopment Today? E.I.A.L. Logo

Estudios Interdisciplinarios De América Latina Y El Caribe, 14(2). Retrieved April 18, 2016.
} 


\section{Final Considerations}

The model of India's pharmaceutical industry is a highly prominent one. Not only did the country manage to rid itself of foreign influence, but it also managed to sustain growth and selfreliance to the point of exerting its influence in Western markets. In a discussion paper, T.C James voiced his concern about the industry's increased imports of bulk drugs from China ${ }^{48}$. The paper argues that the bulk drug imports from china (as a percentage of total bulk drug supply in India) increased from 0.3 percent in 1991 to 47.61 percent in 2012. James mainly contends that the worrisome aspect is not merely the importing of drugs, but it is rather the importing of drugs form one single source, which is strategically disadvantageous to India. Since it is well established that India is a quality manufacturer of medications (for domestic and export purposes), there is a growing concern that the import of bulk materials from China could tamper with the quality of the manufactured medicine. Based on current evidence, we cannot establish a dependency relationship between India and China. This trend lacks an important aspect of dependency theory; there is no evidence that China is importing bulk materials from India and reselling them as consumer goods at a higher price. It can therefore be said that India is not dependent on China for bulk drug importation.

There remains the question of whether India's pharmaceutical market model could be replicated in other third-world countries across different sectors. The Indian pharmaceutical model has already inspired other countries to follow in India's footsteps. For instance, countries such Indonesia and the Philippines already adopted patent laws that are modeled after India' ${ }^{49}$. This model has proven to be worrisome to drug companies, which see it as an attack on intellectual rights. To an extent, India's model does not seem to be a one-size-fits-all. In previous sections, the case of Mexico's steroid hormone industry was explored in depth ${ }^{50}$. India's first step towards

\footnotetext{
48 James, T. (2014). India's Growing Dependence on Imports in the area of Bulk Drugs.

${ }^{49}$ Andrade, C., Shah, N., \& Chandra, S. (2007). The new patent regime: Implications for patients in India. Indian Journal of Psychiatry Indian J Psychiatry, 49(1), 56. doi:10.4103/0019-5545.31520

50 ibid
} 
breaking out of dependency was to implement policy changes; however, the same step did not work effectively for Mexico. In fact, due the overarching influence of the multinational corporations over local Mexican political actors, the government repeatedly failed to pass any policy amendments. Perhaps the starting point for each country towards the direction of sustainable growth and competition is different. But that is not to say that other countries will not succeed in replicating India's model. In a sense, the replication of the model is dependent on the political, historical and economic context of said country. First of all, the local government has to target the political actors and steer them in the direction of policy amendments that favor the local state and its people. Once that has been implemented, the government may start passing legislation gradually. In essence, a government's eventual goal by implementing policy changes is to reach pharmaceutical anatomy, which Gareffi defines as "a country's ability to fulfill the prescription drug needs of its populations especially in the face of structural constraints" ${ }^{51}$. We also need to keep in mind that each country has different issues to address. Not all countries need to implement patent law amendments like India. For instance, to further pursue action in regards to manufacturing antivirals locally, Brazil's government has been attempting to link industrial and health policies. By doing that, the Brazilian government is essentially looking to make the local atmosphere more favorable for the domestic manufacture of drugs and their basic formulations ${ }^{52}$. In going forward, countries should assess what obstacles there are to their pharmaceutical anatomy, and then try to address these challenges on a structural level.

${ }_{52}^{51}$ Flynn, M. Pharmaceutical autonomy and public health in Latin America: State, society, and industry in Brazil's AIDS program. Foreword. 52 ibid 


\section{Work Cited}

Young-Powell, A., \& Page, L. (2014). One in five students have taken the study drug modafinil. Retrieved April 3, 2016, from http://www.theguardian.com/education/abby-and-libbyblog/2014/may/08/one-in-five-students-have-taken-study-drug-modafinil

Siddiqui, Z. (2014, March 13). FDA bans imports from Sun Pharma plant in India crackdown. Retrieved March 27, 2016, from http://www.reuters.com/article/us-sun-pharma-india-fdaidUSBREA2C09S20140313

Sahu, S. (n.d.). Globalization and the Indian Pharmaceutical Industry.

Rushton, C. (2015). Company hikes price 5,000\% for drug that fights complication of AIDS, cancer. Retrieved April 2, 2016, from

http://www.usatoday.com/story/news/health/2015/09/18/company-hikes-price-5000-drug-fightscomplication-aids-cancer-daraprim/32563749/

Palmer, E. (2014, March 13). Sun Pharma plant joins the FDA list of banned Indian facilities. Retrieved March 28, 2016, from http://www.fiercepharmamanufacturing.com/story/sun-pharmaplant-joins-fda-list-banned-indian-facilites/2014-03-13

Nuvigil Official Website. (n.d.). Retrieved March 27, 2016, from http://nuvigil.com/

Nuvigil (armodafinil) Uses, Dosage, Side Effects. (n.d.). Retrieved April 2, 2016, from http://www.drugs.com/nuvigil.html

NUVIGIL FDA APPROVAL. (n.d.). Retrieved April 3, 2016.

Lamittana, J. (2015, September 21). Here's A Way For Pharma To Prevent Outrageous Generic Price Increases -- And Help Its Reputation. Retrieved March 24, 2016, from http://www.forbes.com/sites/johnlamattina/2015/09/21/heres-a-way-for-pharma-to-preventoutrageous-generic-price-increases-and-help-its-reputation/\#ca5a75b31872

James, T. (2014). India’s Growing Dependence on Imports in the area of Bulk Drugs.

Greene, W. (2007). The Emergence of India's Pharmaceutical Industry and Implications for the U.S. Generic Drug Market.

Gereffi, G. (1978). Drug firms and dependency in Mexico: The case of the steroid hormone industry.International Organization Int. Org., 32(01), 237. doi:10.1017/s002081830000391x

Generic Drug Database with Price Details (India). (n.d.). Retrieved March 24, 2016, from http://www.medindia.net/drug-price/ 
Flynn, M. (n.d.). Pharmaceutical autonomy and public health in Latin America: State, society, and industry in Brazil's AIDS program.

Ferraro, V. (1996). Dependency Theory: An Introduction.

Drug Price Search- Rx Price Quotes. (n.d.). Retrieved April 1, 2016, from

https://www.rxpricequotes.com/

Daraprim oral :. (n.d.). Retrieved March 26, 2016, from http://www.webmd.com/drugs/2/drug634/daraprim-oral/details

CorePharma and GlaxoSmithKline conclude agreement on US rights for Dexedrine ${ }^{\circledR}$, Albenza ${ }^{\circledR}$ and Daraprim ${ }^{\circledR}$ | GSK. (n.d.). Retrieved April 2, 2016, from http://us.gsk.com/enus/media/press-releases/2010/corepharma-and-glaxosmithkline-conclude-agreement-on-usrights-for-dexedrineandreg-albenzaandreg-and-daraprimandreg

Levy, D. L., \& Prakash, A. (2003). Bargains Old and New: Multinational Corporations in Global Governance.Business and Politics, 5(2). doi:10.2202/1469-3569.1051

Bajaj, V., \& Pollack, A. (2012). India Orders Bayer to License a Patented Drug. Retrieved April 19, 2016, from http://www.nytimes.com/2012/03/13/business/global/india-overrules-bayerallowing-generic-drug.html?_r=0

Make sure you have this looked at for grammar and punctuation, including commas and punctuation associated $\mathrm{w} /$ footnote numbers. 